\title{
Identification, Pathogenicity, and Fungicide Sensitivity of Colletotrichum Spaethianum Isolates, the Causal Agents of Anthracnose of Daylily in Shanghai, China
}

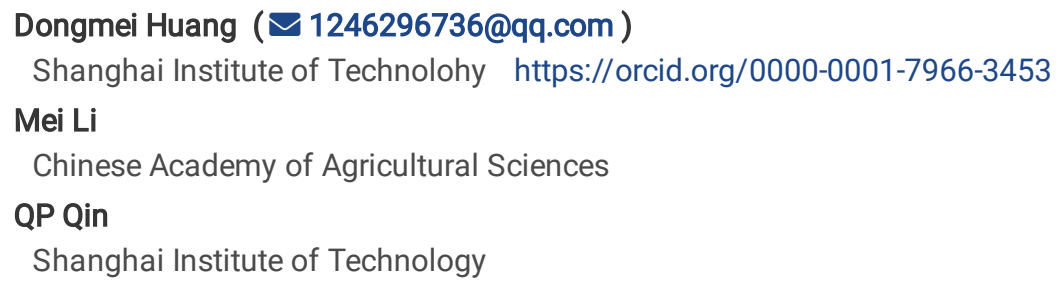




\section{Abstract}

Anthracnose caused by Colletotrichum spp. is a common disease of daylily (Hemerocallis fulva) and results in large economic losses. In this study, typical leaves suspected to be infected with anthracnose were collected, and two isolates were obtained by tissue separation combined with single spore separation. Based on the analysis of morphological characteristics, multi-gene phylogenetic analyses (ITS, GAPDH, ACT, and TUB2) and pathogenicity tests, both isolates were identified as Colletotrichum spaethianum. Pathogenicity tests showed that both isolates were able to cause typical daylily anthracnose symptoms. Fungicide susceptibility analyses showed that the two isolates were highly sensitive to fungicides, including zineb, difenoconazole, captan, and carbendazim, based on the inhibition of mycelial growth with $\mathrm{EC}_{50}$ values ranged from 0.0903 to $3.402 \mu \mathrm{g} / \mathrm{mL}$. This is the first report of C. spaethianum causing daylily anthracnose in China. This study provided a comprehensive reference for the pathogen, symptoms and pesticide prevention of daylily anthracnose, which may help the sustainable management of daylily anthracnose.

\section{Introduction}

Daylily is a herbaceous perennial plant belonging to the family Asphodelaceae, subfamily Hemerocallidoideae (Byng et al., 2016). Daylily is a popular plant that is widely used in landscaping. In recent years, daylily has been more widely used. The Asian market demand for daylily is gradually increasing, especially in China. Daylily is often affected by various diseases, such as rust disease, leaf blight, leaf spot disease and anthracnose (Mostert et al., 2008; Bai et al., 2012; Vieira et al., 2014; Gao et al., 2020a). Daylily anthracnose is common, especially in Hemerocallis middendorfii and Hemerocallis fulva kwanso. Severe infection can result in the death of foliage and the reduced marketability of the plants.

Anthracnose is a disease caused by the Colletotrichum fungus, which has more than 190 recognized species (Jayawardena et al., 2016). The host range and characteristics of each species are different, but anthracnose on many host plants is often caused by compound infection with multiple species (Liu et al., 2016). In preliminary study, Colletotrichum species were distinguished by spores, bristle size and shape, or host plants (Sutton, 1992). However, the symptom of anthracnose is simple, and the morphological differences between species are small. It is difficult to accurately distinguish different Colletotrichum spp. through morphological identification alone because of the variable morphology and the small differences of some conidia (Moriwaki et al., 2002). For example, Liu et al. (2016) isolated 173 Colletotrichum isolates from peppers, and Liu et al. (2020) isolated 78 Colletotrichum isolates from blueberries, all of which had similar morphological characteristics and caused the same symptoms. The conidia of all Colletotrichum are oval- or crescent-shaped, and transparent or pale yellow in color.

With the development of molecular biology, classification based on rDNA internal transcribed spaces (ITS) sequences becomes a commonly used method for fungal classification. The ITS sequence is a highly tandem repeat sequence with a conserved length, generally between 650-750 bp. In addition, the evolution rate of ITS is fast, which can provide abundant mutation sites and information sites, and can be used to effectively distinguish fungi (Elder and Turner, 1995; Schoch et al., 2012). Hu and Zhang (2009) identified C. higginsianum a causal agent of anthracnose on Arabidopsis thaliana, through ITS. Since many Colletotrichum are complex species, including many biologically independent species, the ITS sequence alone cannot effectively distinguish the cryptic species of the complex species (Crouch et al., 2009; Weir et al., 2012). At present, the combination of morphological characteristics and multi-gene phylogenetic analyses to distinguish Colletotrichum has been widely used to identify pathogens and solve classification problems (Sharma et al., 2015). Cara et al. (2020) identified the fungal pathogen that causes olive anthracnose as $C$. acutatum through ITS, glyceraldehyde-3-phosphate dehydrogenase (GAPDH), actin (ACT), chitin synthase (CHS-1), and beta-tubulin (TUB2) genes. Li et al. (2021) identified the fungal pathogen that causes pepper anthracnose as $C$. gloeosporioides using a similar method.

In 2011, daylily anthracnose was first reported in nurseries in Vitória da Conquista, northeastern Brazil, and it was confirmed that $C$. spaethianum could cause the disease (Vieira et al., 2014). However, the understanding of the disease is inadequate. The management of daylily anthracnose in production has mainly been conducted through the use of fungicides. Due to the lack of knowledge about the disease, the improper use of fungicides affects the environment. At present, there is little available information about the prevention and control of daylily anthracnose disease. The objective of the current study was to identify fungal isolates that associated with anthracnose of daylily using a combination of morphological characteristics and multi-gene phylogenetic analyses, and to analyze the pathogenicity and fungicides susceptibility of the fungal isolates, providing information for daylily anthracnose prevention and control.

\section{Materials And Methods}

\section{Sample collection and isolation}


Ten daylily leaves with anthracnose disease symptoms were collected from the Shanghai Institute of Technology, China. According to the method used by Zhou et al, (2015), the characteristics of daylily leaves suspected to be infected with anthracnose were observed and recorded. The samples were stored in sterile polythene bags and brought to the laboratory for stereomicroscope (Koppace, 3.5X-180X, China) examination. The isolation and purification of fungal isolates were performed based on the tissue separation method combined with the single spore separation method. The lesion margin pieces were cut into square pieces with sides of $2-3 \mathrm{~mm}$ and sterilized with $75 \%$ ethanol $\left(\mathrm{CH}_{3} \mathrm{CH}_{2} \mathrm{OH}\right)$ for $30 \mathrm{~s}$, and rinsed three times with distilled sterile water in an ultra-clean workbench. Excess moisture was blotted from diseased patches with filter papers, and they were placed on the PDA medium (potato dextrose agar medium: potato $200 \mathrm{~g}$, glucose $10 \mathrm{~g}$, agar powder $10 \mathrm{~g}$, and added distilled water constant volume to $1 \mathrm{~L}$ ) plate, which was then placed in an incubator at $25 \pm 1^{\circ} \mathrm{C}$ in the dark for seven days. Spores were removed from the lesion margin pieces using sterilized dissect needle, transferred to clear WA medium (water agar medium: agar powder $10 \mathrm{~g}$, and added distilled water constant volume to $1 \mathrm{~L}$ ), and then scattered single spores were transferred to another WA medium slant and purified until single spores were obtained. The pure cultures were obtained and stored on PDA slants at $4^{\circ} \mathrm{C}$.

\section{Morphological analysis}

After culturing on PDA at $25 \pm 1^{\circ} \mathrm{C}$ in the dark for $7 \mathrm{~d}$, the macroscopic colony characters and microscopic characteristics of two fungal isolates, including the colony, mycelial appressoria, conidia, and conidial appressoria, were initially observed. The conidia were placed on the glass coverslip of a microscope slide. Mycelial appressoria were observed using the slide culture technique. The morphological characteristics of conidia were observed and a morphological map was constructed under the light microscope (Leica, DM4 B, Germany). The colony diameter of isolates from $1 \mathrm{~d}$ to $7 \mathrm{~d}$ after inoculation was assessed using the cross measurement method (Sun et al., 2020b). Fifty conidia were randomly selected to measure their size at 60 -fold magnification.

\section{DNA extraction, PCR amplification, and sequencing}

The genomic DNA of two fungal isolates was extracted from fresh mycelia grown on PDA for $7 \mathrm{~d}$ using the UNIQ-10 Column Fungal Genomic DNA Isolation Kit, following the manufacturer's instructions (Sangon, Shanghai, China). The quality of DNA was analyzed by $1.5 \%$ (w/v) agarose gel electrophoresis and Nanodrop One, and stored at $-20^{\circ} \mathrm{C}$ for PCR analysis.

ITS, ACT, GAPDH, and TUB2 genes of the isolated DNA were amplified and sequenced using their primer pairs: ITS1/ITS4 (ITS, Gardes and Bruns, 1993), GDF1/GDR1 (GAPDH, Guerber et al., 2003), ACT-512F/ACT-783R (ACT, Carbone and Kohn 1999), and T1/T2b (TUB2, Glass and Donaldson, 1995), respectively (Table S1). PCR amplification was carried out using Taq DNA polymerase in a PCR Thermal Cycler (Bio-Rad, $\mathrm{S} 1000$, America) in a total volume of $30 \mu \mathrm{L}$. The reaction conditions were pre-denaturation at $94{ }^{\circ} \mathrm{C}$ for 5 min; denaturation at $94{ }^{\circ} \mathrm{C}$ for $30 \mathrm{~s}$, annealing at a temperature depending on the primers for $30 \mathrm{~s}$, extension at $72{ }^{\circ} \mathrm{C}$ for 2 min, cycling for 35 times; and extension at $72{ }^{\circ} \mathrm{C}$ for another $5 \mathrm{~min}$. All PCR products were purified with the anPrep Column PCR Product Purification Kit, according to the manufacturer's instructions. All the above kits and primers were provided by Sangon, Shanghai, China. The purified PCR products were sequenced (Sangon, Shanghai, China). The consensus sequences were deposited in GenBank (Table 1).

\section{Sequence analysis and phylogenetic tree construction}

A multigene phylogenetic tree was constructed using the method described by Liu et al. (2020). The homology of sequences from the isolates was compared with the NCBI database (https://blast.ncbi.nlm.nih.gov/Blast.cgi) by blastn and further analyzed using Clustal (https://www.ebi.ac.uk/Tools/msa/clustalo/). The maximum likelihood method was used to construct the multigene phylogenetic tree based on ITS, GAPDH, ACT, and TUB2 genes by MEGA7.0 with 1000 bootstrap replicates. Alternaria alternata (strain: AA2-8) was used as the outgroup. GenBank accession numbers of all the isolates used in the phylogenetic analyses are listed in Table 1.

\section{Pathogenicity tests}

The pathogenicity of the two fungal isolates was tested on one-year-old healthy daylily 'Rosy Rhino' × 'Spacecoast Storm' hybrids. Green, fulllength leaves from living daylily plants were collected by cutting the leaves at the base of a division. The cut leaves were immediately rinsed under running water and air-dried in an upright position in a glass beaker with the cut ends immersed in distilled water. In an ultra-clean workbench, distilled water was used to wash the impurities on the surfaces of the leaves. The leaves was then sterilized with $70 \%$ ethanol for $30 \mathrm{~s}$ to sterilize the surface, and rinsed three times with distilled sterile water to remove the residual alcohol on the leaf surfaces. To help delay leaves senescence, leaves were cut into $4-5 \mathrm{~cm}$ sections and placed in $9 \mathrm{~cm}$ borosilicate glass culture dishes covered with filter paper moistened with $0.1 \mu \mathrm{g} / \mathrm{mL}$ gibberellic acid solution (Buck, 2013). The daylily leaves were treated three ways: non-wound, stab wound, and excised wound treatments. In the non-wound treatment, no mechanical damage was done to the leaves. In the stab treatment, the leaves were stabbed using a self-made 5-needle plum-blossom needle to stab the central position of two side of the leaves veins. In the excised wound treatment, field pruning was applied by cutting a small opening about $2 \mathrm{~cm}$ long on one side of the leaves. 
A mycelial plug with an area of about $0.25 \mathrm{~cm}^{2}$ was taken from the edge of the active growing colony of each isolate with a hole punch (Gao et al., 2020b), and the mycelial plug was inoculated on the leaf wounds with the fungal mycelia facing the leaf. A moist filter paper larger than the mycelial plug was placed on the surface of the it to keep the moisture. For the controls, only the PDA medium and wet filter paper were placed on the leaves without mycelial plug. The experimental design consisted of six replicate dishes (each with a single leaf segment) for each treament and each isolate of daylily. Borosilicate glass culture dishes were placed in a light incubator and moisturized at $25^{\circ} \mathrm{C}$ with 12 $\mathrm{h}$ photoperiod. All experiments were repeated twice. The onset time and pathogenicity of leaves were observed and recorded every day. If the typical symptoms produced by artificial inoculation were the same as the original symptoms under natural conditions, and the control leaves did not develop the disease, then the infected plants were inoculated for the re-separation of pathogenic fungi, and Koch's postulates were verified (Liu et al., 2020).

\section{Fungicide susceptibility analysis}

Fungicide susceptibility analysis of the two fungal isolates from daylily was carried out (Arikan, 2007). The sensitivity of the isolates to four fungicides was determined by the mycelial growth rate method (Liang et al., 2015). All fungicides were provided by Chinese companies, and the detailed information is shown in Table 2. According to the concentrations of fungicides used in production, the experimental concentrations of the fungicides were designed by the fractional dose method. The fungicides were prepared into a solution and added to the PDA medium. The solution was spread to the whole medium by gently shaking the dishes.

A mycelial plug $\left(0.25 \mathrm{~cm}^{2}\right)$ was obtained by a hole punch, and it was inoculated on the middle of a borosilicate glass culture dish with a diameter of $9 \mathrm{~cm}$ that was filled with PDA medium with fungicides, with the fungal mycelia facing down the agar. PDA plates with the same amount of sterile water were used as controls, and each fungicide and concentration had three independent replicates. PDA plates were incubated in a constant temperature incubator at $25 \pm 1^{\circ} \mathrm{C}$ for $7 \mathrm{~d}$ in the dark. For each plate, the colony diameter from $1 \mathrm{~d}$ to $7 \mathrm{~d}$ was assessed by using the cross measurement method. The percentage of growth inhibition in response to each fungicide at varying concentrations was calculated with the control plate as a reference (Liang et al., 2015). The calculation was as follows:

inhibitory effect $(\%)=[$ (Fungal colony diameter of the control - fungal colony diameter of the treatment) / (Fungal colony diameter of the control -0.5$)] \times 100 \%$

Through the linear regression relationship between the mass concentration pair value $(X)$ and the probability value of inhibition rate $(Y)$, the toxicity regression equation was $\mathrm{Y}=\mathrm{a} X+\mathrm{b}$. The mass concentration $\mathrm{EC}_{50}$ (effective inhibiting concentration) values in the effective inhibition were obtained (Ma et al., 2009), then the sensitivity of each fungicide to the pathogen was compared. This experiment was conducted twice.

\section{Results}

\section{Symptomatology}

Shanghai Institute of Technology, as the sample collection site of this experiment, has 33,000 square meters of daylily planting area, where the incidence of anthracnose reach $25 \%$. Based on field observations, anthracnose symptoms on daylily leaves were recorded. The initial stage of leaf disease was reddish-brown lesions with a yellow halo, which later expanded into reddish brown stripes. If the disease spots occurred at the tip of the leaf, the tip died and then spread down the vein to kill the upper part of the leaf. If the disease spots occurred in the leaf margin, the leaves were twisted and deformed, and the leaves changed from green to greyish yellow. The junction of the disease was reddish brown, and the center was gray-brown. When the disease was serious, many disease spots connected into large spots, which eventually led to the death of the whole leaf and dense black spots on the leaf surface (Figure 1).

\section{Morphological characterization}

Two isolates were obtained by the tissue separation method combined with the single spore separation method. These isolates were named HFCS1 and HFCS2. After $7 \mathrm{~d}$ of culture on PDA medium at $25 \pm 1{ }^{\circ} \mathrm{C}$, the two isolates had similar morphology. They produced colonies with uniform edges. The colonies appeared felted with aerial mycelia that were light gray to grayish white on the upper surface and dark gray to olive gray to light gray on the lower surface, with a cottony texture, high density, and low presence of sectors (Figure 2A-D). The hyphae produced were initially pale yellow in color, smooth, and cylindrical at the bases with rounded apexes. Later mycelia were twisted, branched more, separated, and were pale in color (Figure 2E, F). The average mycelial growth rate of HFCS1 was $9.3 \pm 2.4 \mathrm{~mm}^{\text {day }}{ }^{-1}$, while that of HFCS2 was $10.5 \pm 3.1 \mathrm{~mm}^{-1 a y}{ }^{-1}$. Conidia were both hyaline, aseptate, curved or slightly curved, and had a round or somewhat acute apex and base (Figure 2G, H). The conidia of HFCS1 had lengths of 15.5-21.6 (M \pm SD = 19.1 \pm 4.71$) \mu \mathrm{m}$, widths of 3.6-5.4 $(4.7 \pm 0.42) \mu \mathrm{m}$, and length/width (L/W) ratios of 3.34-5.61, while those of HFCS2 had lengths of 12.3-25.5 (M $\pm S D=20.1 \pm 3.16) \mu \mathrm{m}$, widths of $4.2-5.7$ (5.19 \pm $0.51) \mu \mathrm{m}$, and length/width (L/W) ratios of 2.87-5.89. The conidia of HFCS1 were more elongated than those of HFCS2. The appressoria of 
two isolates were both solitary, mostly simple, rarely lobed, and dark brown in color. The appressoria of HFCS1 were ovate (Figure 2I), while those of HFCS2 were clavate (Figure 2J).

The morphological characteristics of the two isolates were similar to those of the species in the C. spaethianum, C. graminicola, and C. truncatum species complexes, which have curved and falcate conidia and ovoid, dark brown spores (Du et al., 2005; Bonacci et al., 2021). However, this was not enough to distinguish the Colletotrichum species of the two isolates based on morphology alone, and further identification was needed.

\section{Phylogenetic analysis}

Approximately 591-bp (HFCS1) and 550-bp (HFCS2) DNA fragments were obtained using the primer pairs ITS1 and ITS4. In addition, PCR amplification and sequencing were carried out on the GAPDH gene with about 262-bp and 264-bp sequences, the ACT gene with 234-bp and 247-bp sequences, and the TUB2 gene with 755-bp and 606-bp sequences for HFCS1 and HFCS2, respectively. The sequence analysis shows that HFCS1 and HFCS2 could only be distinguished by TUB2 sequences and not by ITS, GAPDH or CHS-1 sequences. The similarity between the two isolates and the reference sequence of $C$. spaethianum was greater than $97 \%$. The multigene phylogenetic tree was constructed by MEGA software with $A$. alternata (strain: AA2-8) as the outgroup based on multi-gene phylogenetic analyses (ITS, GAPDH, ACT and TUB2 genes). The two isolates isolated in this study were closely related to $C$. spaethianum on the same branch (Figure 3 ).

\section{Pathogenicity evaluation}

After inoculation on wounded daylily leaves, all the leaves showed anthracnose on inoculated leaves, which exhibited symptoms similar to the symptoms of leaf samples collected from field (Figure 1). Initially, the stabbed leaves showed small and yellowish halo symptoms after inoculation for $2 \mathrm{~d}$ (Figure 4B). Five days after inoculation, the water-soaked spots appeared that expanded rapidly and irregularly (Figure 4C). Seven days after inoculation, as the disease progressed, the enlarged spots merged, and severe leaf blight with concentric black rings formed in the enlarged lesions (Figure 4D, E). The symptoms of excised leaves were similar to those of stabbed leaves in the early stage (Figure 4G$\mathrm{H})$, but the two isolates exhibited higher aggressiveness in stabbed leaves (Figure $4 \mathrm{I}-\mathrm{J}$ ). There were no symptoms in the non-wounded leaves inoculated with the fungus (Figure $4 \mathrm{~L}-0$ ). None of the controls showed symptoms (Figure 4A, F, K). The symptoms caused by HFCS1 and HFCS2 were similar, although the symptoms caused by HFCS2 spread faster and caused larger wounds (on average, each wound was $0.2 \mathrm{~cm}$ larger $7 \mathrm{~d}$ after the inoculation).

The typical symptoms produced by artificial inoculation confirmed with the original symptoms under natural conditions, and the morphological characteristics and ITS sequences of the re-isolated fungi were consistent with those of the first isolated fungi. Therefore, Koch's postulates were confirmed. The results proved that the inoculated fungus was the pathogen of daylily anthracnose. Combined with morphological characteristics, multigene phylogenetic analysis, and pathogenicity analysis, the two fungal isolates from daylily were identified as C. spaethianum.

\section{Evaluation of fungicide susceptibility}

The effect of fungicides was assessed on the qualitative growth of mycelium after the inoculation of mycelial plug on in PDA medium for $7 \mathrm{~d}$. The results showed that all four fungicides had inhibitory effects on the two isolates from daylily (Figure 5-6). The EC $\mathrm{E}_{50}$ of mycelial growth was calculated to determine the level of fungicide sensitivity of the pathogen (Table 3). Difenoconazole and carbendazim presented remarkable antifungal activity against the two isolates tested with $\mathrm{EC}_{50}$ values lower than $1 \mu \mathrm{g} / \mathrm{mL}$. The inhibitory effects of zineb and captan were the second-higher, with $\mathrm{EC}_{50}$ values higher than $1 \mu \mathrm{g} / \mathrm{mL}$ and lower than $5 \mu \mathrm{g} / \mathrm{mL}$. From the control groups of the two isolates, the mycelial growth rate of HFCS2 was higher than that of HFCS1, and the EC $_{50}$ values of HFCS2 treated with zineb were 1.6 times as much as those of HFCS1. However, the $\mathrm{EC}_{50}$ value of HFCS2 treated with captan was half as much as that of HFCS1, and the EC Ho $_{50}$ alue of HFCS1 treated with difenoconazole of HFCS1 was 4.9 times as much as that of HFCS2. The results showed that the susceptibility of the two isolates from daylily to four fungicides was significantly different.

\section{Discussion}

Anthracnose causes extensive yield losses in many plants, including daylily, especially in warm and rainy seasons. In this investigation, daylily with suspected anthracnose disease symptoms were sampled from the Shanghai Institute of Technology, Shanghai, China. The incidence of anthracnose, along with other diseases such as rust disease, is particularly prevalent during the rainy season.

According to the standard of morpho-taxonomic criteria, the fungal isolates in this study were classified as Colletotrichum species. The morphological characteristics of them were similar to those of the species in the C. spaethianum, C. graminicola, and C. truncatum species complexes. Then the two isolates were further identified by the analysis of restricted polymorphisms in the DNA amplification region. 
According to the result of sequence analysis, the ITS, GAPDH and CHS-1 sequences of HFCS1 and HFCS2 were not significantly different, the sequence similarity was up to $97 \%$. And the TUB2 sequence (77\% sequence similarity) was the one that really distinguishes the two isolates. The multigene phylogenetic tree based on multi-locus genes including ITS, GAPDH, CHS-1, and TUB2 sequences provided a good method of distinguishing of the two isolates, and they were clustered together with $C$. spaethianum with high bootstrap support (98\% of HFCS1 and $C$. spaethianum CCSX3, $80 \%$ of HFCS2 and C. spaethianum 1137).

Pathogenicity tests of two isolates from daylily in this study showed that the isolates were pathogenic on daylily leaves after wounding the surface, but they were produced no apparent infection on non-wounded leaves. This might illustrate the importance of the cuticle acting as a barrier to infection by $C$. spaethianum $\llbracket$ Alkan et al., 2015; Fukada et al., 2019). Combined with morphological characteristics, multi-gene phylogenetic analysis, and pathogenicity tests, the two isolates from daylily leaves were identified as $C$. spaethianum.

C. spaethianum is a very common causal agent of anthracnose worldwide, and it has been found in a number of other hosts, including Lilium brownii, Allium ledebourianum, and Polygonatum cyrtonema (Yang et al., 2009; Salunkhe et al., 2018; Ma et al., 2020). In addition to anthracnose, C. spaethianum has also been identified as a causal agent of leaf spot (Guo et al., 2013; Zhong et al., 2019; Sun et al., 2020a). The present study identified $C$. spaethianum isolates as the pathogenic fungi of daylily anthracnose after the species was previously reported in Brazil (Vieira et al., 2014). However, none of the systematic studies of the disease have been conducted. This survey focused on the pathogenic fungi causing anthracnose-like symptoms in fields, and the two isolates collected in the current study could have been primary or secondary invaders. The isolates tested in this study were confirmed to be capable of causing anthracnose-like symptoms on wounded leaves of daylily, but no obvious symptoms were shown on non-wounded leaves. This may indicated that the two fungal isolates in this study were wound pathogens on daylily.

For the effective development and deployment of host resistance, and the reduction of fungicide application and risks to the environment, it is necessary to understand the sensitivity of the pathogens causing daylily anthracnose to those fungicides commonly used in daylily disease control. Zineb, captan, difenoconazole, and carbendazim are all commonly used in production, these compounds are currently labeled for the control of anthracnose (Patiño-Vera et al., 2005; Abbott and Beckerman, 2018; Zhang et al., 2020b; Wang et al., 2020). In this study, the two C. spaethianum isolates from daylily leaves showed different sensitivity to zineb, difenoconazole, captan and carbendazim, with $\mathrm{EC}_{50}$ values ranging from 0.0903 to $3.402 \mu \mathrm{g} / \mathrm{mL}$. The $\mathrm{EC}_{50}$ values of $C$. spaethianum varied greatly among the fungicides, which should be further investigated to improve the efficacy of daylily anthracnose management strategies.

In this study, based on the resistance ratio and $\mathrm{EC}_{50}$ values, difenoconazole and carbendazim would be expected to provide better control than zineb and captan, and the sensitivity of HFCS1 to carbendazim was higher than that of difenoconazole with a 0.13 difference in $\mathrm{EC}_{50}$ values. The sensitivity of HFCS2 to difenoconazole was 5.81 times higher than its sensitivity to carbendazim. Studies showed that Colletotrichum is highly sensitive to carbendazim, with $\mathrm{EC}_{50}$ value lower than $10 \mu \mathrm{g} / \mathrm{mL}$ (Kim et al., 2020; Wang et al., 2020; Zhong et al., 2021). However, study of Gama et al. (2020) showed that there is no relationship between $C$. acutatum inhibition and fungicide concentration, and $\mathrm{EC}_{50}$ values for carbendazim could not be determined. The above results indicate that the susceptibility of Colletotrichum to fungicides is probably related to species, and there are differences among different strains from the same species.

\section{Declarations}

\section{Acknowledgements}

This study was supported by Science and Technology agriculture Project of Shanghai (No. 2019-02-08-00-08-F01107), funded by Shanghai Agricultural Commission. We thank LetPub (www.letpub.com) for its linguistic assistance during the preparation of this manuscript.

\section{Author contributions}

QQ was responsible for the guidance of experiments, the revision of manuscript, the purchase of experimental samples and the supervision of experiments.. DH was responsible for the designed and performed of experiments, carried out data analysis and wrote manuscript. ML was responsible for the culture of experimental samples.

\section{Data availability}

DNA sequences used in this present study are available in GenBank.

\section{Conflict of Interest}

The authors declare no conflict of interest in this study. 


\section{Ethics approval}

Not applicable

\section{Conflict of interest}

The authors declare no competing interests.

\section{Open Access}

This article is licensed under a Creative Commons Attribution 4.0 International License, which permits use, sharing, adaptation, distribution and reproduction in any medium or format, as long as you give appropriate credit to the original author(s) and the source, provide a link to the Creative Commons licence, and indicate if changes were made. The images or other third party material in this article are included in the article's Creative Commons licence, unless indicated otherwise in a credit line to the material. If material is not included in the article's Creative Commons licence and your intended use is not permitted by statutory regulation or exceeds the permitted use, you will need to obtain permission directly from the copyright holder. To view a copy of this licence, visit http://creativecommons.org/licenses/by/4.0/.

\section{References}

1. Abbott, C.P., \& Beckerman, J.L. (2018). Incorporating adjuvants with captan to manage common apple diseases. Plant Disease, 102(1),231-236. https://doi.org/10.1094/PDIS-05-17-0629-RE

2. Afanador-Kafuri, L., González, A., Gañán, L., Mejía, J.F., Cardona, N., \& Alvarez, E. (2014). Characterization of the Colletotrichum species causing anthracnose in Andean Blackberry in Colombia. Plant Disease, 98(11),1503-1513. https://doi.org/10.1094/PDIS-07-13-0752-RE

3. Alkan, N., Friedlander, G., Ment, D., Prusky, D., \& Fluhr, R. (2015). Simultaneous transcriptome analysis of Colletotrichum gloeosporioides and tomato fruit pathosystem reveals novel fungal pathogenicity and fruit defense strategies. New Phytologist, 205(2),801-15. https://doi.org/10.1111/nph.13087

4. Arikan, S. (2007). Current status of antifungal susceptibility testing methods. Medical Mycology, 45(7),569-87. https://doi.org/10.1080/13693780701436794

5. Bai, Q.R., Han, S., Xie, Y.Y., Dong, R., Gao, J., \& Li, Y. (2012). First report of Daylily leaf streak caused by Kabatiella microsticta in China. Plant Disease, 96(10),1579. https://doi.org/10.1094/PDIS-04-12-0381-PDN

6. Barimani, M., Pethybridge, S.J., Vaghefi, N., Hay, F.S., \& Taylor, P.W.J. (2013). A new anthracnose disease of pyrethrum caused by Colletotrichum tanaceti sp. Nov, Plant Pathology, 62(6),1248-1257. https://doi.org/10.1111/ppa.12054

7. Bonacci, M., Formento, Á.N., Morales, M.C., Orlando, J., Ibáñez, F., Sartori, M., Etcheverry, M., Nesci, A., \& Barros, G. (2021). Conyza bonariensis as an alternative host for Colletotrichum species in Argentina. Journal of Applied Microbiology, 130(5),1656-1670. https://doi.org/10.1111/jam.14879

8. Buck, J.W. (2013). Identification of pathotypes in the daylily rust pathogen Puccinia hemerocallidis. Journal of Phytopathology, 161(1112),784-790. https://doi.org/10.1111/jph.12134

9. Byng, J.W., Chase, M.W., Fay, M.F., Other members of the angiosperm phylogeny group. (2016). An update of the angiosperm phylogeny group classification for the orders and families of flowering plants: APG IV. Botanical Journal of the Linnean Society, 181(1),1-20. https://doi.org/10.1111/boj.12385

10. Crouch, J. A., Tredway, L.P., Clarke, B.B., \& Hillman, B.I. (2009). Phylogenetic and population genetic divergence correspond with habitat for the pathogen Colletotrichum cereale and allied taxa across diverse grass communities. Molecular Ecology, 18(1),123-35. https://doi.org/10.1111/j.1365-294X.2008.04008.x

11. Cara, M., Iliadi, M.K., Lagogianni, C.S., Paplomatas, E., Merkuri, J., \& Tsitsigiannis, D.I. (2020). First report of Colletotrichum acutatum causing anthracnose on olives in Albania. Plant Disease, 14,495-499. https://doi.org/10.1094/PDIS-04-20-0774-PDN

12. Carbone I., \& Kohn L.M.(1999.) A method for designing primer sets for speciation studies in filamentous ascomycetes. Mycologia, 91(3),553-556. https://doi.org/

13. Damm, U., Cannon, P.F., Woudenberg, J.H., \& Crous, P.W. (2012). The Colletotrichum acutatum species complex. Studies in Mycology, 73(1),37-113. https://doi.org/10.3114/sim0010

14. Damm, U., Woudenberg, J.H.C., Cannon, P.F., \& Crous, P.W. (2009). Colletotrichum species with curved conidia from herbaceous hosts. Fungal Diversity, 39,45-87.

15. Damm, U., O'Connell, R.J., Groenewald, J.Z., \& Crous, P.W. (2014). The Colletotrichum destructivum species complex - hemibiotrophic pathogens of forage and field crops. Studies in Mycology, 79,49-84. https://doi.org/10.1016/j.simyco.2014.09.003

Page $7 / 17$ 
16. Du, M., Schardl, C.L., Nuckles, E.M., \& Vaillancourt, L.J. (2005). Using mating-type gene sequences for improved phylogenetic resolution of Colletotrichum species complexes. Mycologia, 97(3), 641-658. https://doi.org/10.1080/15572536.2006.11832795

17. Elder, J.F., \& Turner, B.J. (1995). Concerted evolution of repetitive DNA sequences in eukaryotes. Quarterly Review of Biology, 70(3), 297320. https://doi.org/10.1086/419073

18. Fukada, F., Kodama, S., Nishiuchi, T., Kajikawa, N., \& Kubo, Y. (2019). Plant pathogenic fungi Colletotrichum and Magnaporthe share a common G1 phase monitoring strategy for proper appressorium development. New Phytologist, 222(4),1909-1923. https://doi.org/10.1111/nph.15728

19. Gama, A.B., Baggio, J.S., Rebello, C.S., Lourenço, S.A., Gasparoto, M.C.G., da Silva Junior, G.J., Peres, N.A., \& Amorim, L. (2020). Sensitivity of Colletotrichum acutatum isolates from citrus to carbendazim, difenoconazole, tebuconazole, and trifloxystrobin. Plant Disease, 104(6),1621-1628. https://doi.org/10.1094/PDIS-10-19-2195-RE

20. Gao, J., Zeng, G.P., \& Song, L.S. (2020a). Identification and biological characteristics of pathogen causing leaf spot disease of Hemerocallis fulva. Acta Horticulturae Sinica, 47(01),169-178. In Chinese. https://doi.org/10.16420/j.issn.0513-353x.2019-0343

21. Gao, Y.Y., Li, X.X., He, L.F., Li, B.X., Mu, W., \& Liu, F. (2020b). Effect of Pyrisoxazole on Colletotrichum scovillei Infection and Anthracnose on Chili. Plant Disease, 104(2),551-559. https://doi.org/10.1094/PDIS-06-19-1291-RE

22. Gardes, M., \& Bruns, T.D. (1993). ITS primers with enhanced specificity for basidiomycetes-application to the identification of mycorrhizae and rusts. Molecular. Ecology, 2(2),113-8. https://doi.org/10.1111/j.1365-294X.1993.tb00005.x

23. Glass, N.L., \& Donaldson, G.C. (1995). Development of primer sets designed for use with the PCR to amplify conserved genes from filamentous ascomycetes. Applied \& Environmental Microbiology, 61(4),1323-30. https://doi.org/10.1002/bit.260460112

24. Guarnaccia, V., Gilardi, G., Martino, I., Garibaldi, A., \& Gullino, M.L. (2019). Species diversity in Colletotrichum causing anthracnose of aromatic and ornamental lamiaceae in Italy. Agronomy, 9(10),613-628. https://doi.org/10.3390/agronomy9100613

25. Guerber, J.C., Liu, B., Correll, J.C., \& Johnston, P.R. (2003). Characterization of diversity in Colletotrichum acutatum sensu lato by sequence analysis of two gene introns, mtDNA and intron RFLPs, and mating compatibility. Mycologia, 95(5),872-95. https://doi.org/10.1080/15572536.2004.11833047

26. Guo, M., Pan, Y.M., Dai, Y.L., \& Gao, Z.M. (2013). First report of leaf spot caused by Colletotrichum spaethianum on Peucedanum praeruptorum in China. Plant Disease, 97(10),1380. https://doi.org/10.1094/PDIS-03-13-0246-PDN

27. Hu, S., \& Zhang, J.Z. (2009). Colletotrichum destructivum from cowpea infecting Arabidopsis thaliana and its identity to C. higginsianum. European Journal of Plant Pathology, 125(3),459-469. https://doi.org/10.1007/s10658-009-9495-2

28. Jayawardena, R.S., Hyde, K.D., Damm, U., Cai, L., \& Yan J.Y. (2016). Notes on currently accepted species of Colletotrichum. Mycosphere, 7(8), 1192-1260. https://doi.org/10.5943/mycosphere/si/2c/9

29. Kim, C.H., Hassan, O., \& Chang, T. (2020). Diversity, pathogenicity, and fungicide sensitivity of Colletotrichum species associated with apple anthracnose in South Korea. Plant Disease. 104(11),2866-2874. https://doi.org/10.1094/PDIS-01-20-0050-RE

30. Li, Y., Ma, X., Gai, W., Xiao, L., \& Gong, Z. (2021). First report of Colletotrichum gloeosporioides causing anthracnose on pepper in Shaanxi Province, China. Plant Disease, 23,1-4. https://doi.org/10.1094/PDIS-01-21-0123-PDN

31. Liang, H. J., Di, Y.L., Li, J.L., \& Zhu, F.X. (2015). Baseline sensitivity and control efficacy of fluazinam against Sclerotinia sclerotiorum. European Journal of Plant Pathology, 142(4),691-699. https://doi.org/10.1007/s10658-015-0644-5

32. Liu, F., Tang, G., Zheng, X., Li, Y., Sun, X., Qi, X., Zhou, Y., Xu, J., Chen, H., Chang, X., Zhang, S., \& Gong, G. (2016). Molecular and phenotypic characterization of Colletotrichum species associated with anthracnose disease in peppers from Sichuan province, China. Scientific Reports, 6,32761. https://doi.org/10.1038/srep32761

33. Liu, X., Zheng, X., Khaskheli, M.I., Sun, X., Chang, X., \& Gong, G. (2020). Identification of Colletotrichum species associated with blueberry anthracnose in Sichuan, China. Pathogens, 9(9),718. https://doi.org/10.3390/pathogens9090718

34. Ma, H.X., Feng, X.J., Chen, Y., Chen, C.J., \& Zhou, M.G. (2009). Occurrence and characterization of dimethachlon insensitivity in Sclerotinia sclerotiorum in Jiangsu province of China. Plant Disease, 93(1),36-42. https://doi.org/10.1094/PDIS-93-1-0036

35. Ma, J., Xiao, X., Wang, X., \& Guo, M. (2020). Colletotrichum spaethianum causing anthracnose on Polygonatum cyrtonema in Anhui province, China. Plant Disease. 20,509. https://doi.org/10.1094/PDIS-04-20-0778-PDN

36. Moriwaki, J., Tsukiboshi, T., \& Sato, T. (2002). Grouping of Colletotrichum species in Japan based on rDNA sequences. Journal of General Plant Pathology, 68(4),307-320. https://doi.org/10.1007/PL00013096

37. Mostert, L., Bester, W., Coertze, S., \& Wood, A.R. (2008). First report of daylily rust caused by Puccinia hemerocallidis in the western cape province of South Africa. Plant Disease, 92(7),1133. https://doi.org/10.1094/PDIS-92-7-1133A

38. O'Connell, R.J., Thon, M.R., Hacquard, S., Amyotte, S.G., Kleemann, J., Torres, M.F., Damm, U., Buiate, E.A., Epstein, L., Alkan, N., Altmüller, J., Alvarado-Balderrama, L., Bauser, C.A., Becker, C., Birren, B.W., Chen, Z., Choi, J., Crouch, J.A., Duvick, J.P., Farman, M.A., \& Vaillancourt, 
L.J. (2012). Lifestyle transitions in plant pathogenic Colletotrichum fungi deciphered by genome and transcriptome analyses. Nature Genetics, 44(9),1060-1065. https://doi.org/10.1038/ng.2372

39. Patiño-Vera, M., Jiménez, B., Balderas, K., Ortiz, M., Allende, R., Carrillo, A., \& Galindo, E. (2005). Pilot-scale production and liquid formulation of Rhodotorula minuta, a potential biocontrol agent of mango anthracnose. Journal of Applied Microbiology, 99(3),540-50. https://doi.org/10.1111/j.1365-2672.2005.02646.x

40. Salunkhe, V.N., Anandhan, S., Gawande, S.J., Ikkar, R.B., \& Singh, M. (2018). First report of anthracnose caused by Colletotrichum spaethianum on Allium ledebourianum in India. Plant Disease. 102(10). https://doi.org/10.1094/PDIS-01-18-0104-PDN

41. Schoch, C.L., Seifert, K.A., Huhndorf, S., Robert, V., Spouge, J.L., Levesque, C.A., Chen, W., Fungal Barcoding Consortium, Fungal Barcoding Consortium Author List. (2012). Nuclear ribosomal internal transcribed spacer (ITS) region as a universal DNA barcode marker for Fungi. Proceedings of the National Academy of ences of the United States of America, 109(16),6241-6246. https://doi.org/10.1073/pnas.1117018109

42. Sharma, G., Pinnaka, A.K., \& Shenoy, B.D. (2015). Resolving the Colletotrichum siamense species complex using ApMat marker. Fungal Diversity, 71(1),247-264. https://doi.org/10.1007/s13225-014-0312-7

43. Silva, D.D., Groenewald, J.Z., Crous, P.W., Ades, P.K., Nasruddin, A., Mongkolporn, O., \& Taylor, P.W.J. (2019). Identification, prevalence and pathogenicity of Colletotrichum species causing anthracnose of Capsicum annuum in Asia. IMA Fungus, 10(1),1-32. https://doi.org/10.1186/s43008-019-0001-y

44. Sun, H., Sun, L., Hong, Y., \& Liang, Y. (2020a). First report of anthracnose on Hosta ventricosa caused by Colletotrichum spaethianum in China. Crop Protection, 131,105-104. https://doi.org/10.1016/j.cropro.2020.105104

45. Sun, X., Qi, X., Wang, W., Liu, X., Zhao, H., Wu, C., Chang, X., Zhang, M., Chen, H., \& Gong, G. (2020b). Etiology and symptoms of maize leaf spot caused by Bipolaris spp. in Sichuan, China. Pathogens, 9(3),229-247. https://doi.org/10.3390/pathogens9030229

46. Sutton, B.C. (1992). The genus Glomerella and its anamorph Colletotrichum. Colletorichum biology, pathology and control, $1992: 1-26$.

47. Vieira, W.A.S., Michereff, S.J., Oliveira, A.C., Santos, A., \& Câmara, M.P.S. (2014). First report of anthracnose caused by Colletotrichum spaethianum on Hemerocallis flava in Brazil. Plant Disease. 98(7),997. https://doi.org/10.1094/PDIS-10-13-1026-PDN

48. Wang, Q.H., Fan, K., Li, D.W., Han, C.M., Qu, Y.Y., Qi, Y.K., \& Wu, X.Q. (2020). Identification, virulence and fungicide sensitivity of Colletotrichum gloeosporioides s.s. responsible for walnut anthracnose disease in China. Plant Disease. 104(5), 1358-1368. https://doi.org/10.1094/PDIS-12-19-2569-RE

49. Wang, Q.T., Liu, F., Hou, C.L., \& Cai, L. (2021). Species of Colletotrichum on bamboos from China. Mycologia, 113(2), $450-458$. https://doi.org/10.1080/00275514.2020.1837567

50. Weir, B.S., Johnston, P.R., \& Damm, U. (2012). The Colletotrichum gloeosporioides species complex. Studies in Mycology, 73(1), 115-180. https://doi.org/10.3114/sim0011

51. Yang, Y.L., Liu, Z.Y., Cai, L., Hyde, K.D., \& Ehc, M.K. (2009). Colletotrichum anthracnose of amaryllidaceae. Fungal Diversity, $39(2), 123-146$.

52. Zhang, J., Kang, Y., Xu, X., Xu, T., Li, C., Chen, K., \& Cao, H. (2020a). First report of leaf spot caused by Alternaria alternata on Sonchus asper in china. Plant Disease, 105(2),1-5. https://doi.org/10.1094/PDIS-05-19-0940-PDN

53. Zhang, L., Song, L., Xu, X., Zou, X., Duan, K., \& Gao, Q. (2020b). Characterization and fungicide sensitivity of Colletotrichum species causing strawberry anthracnose in Eastern China. Plant Disease, 104(7), 1960-1968. https://doi.org/10.1094/PDIS-10-19-2241-RE

54. Zhong, J., Li, C.X., Zhong, S.Y., \& Hu, Z. (2019). First report of leaf spot caused by Colletotrichum spaethianum on Paris polyphylla in china. Plant Disease, 104(3). https://doi.org/10.1094/PDIS-09-19-1844-PDN

55. Zhong, S., Miao, J., Liu, X., \& Zhang, G. (2021). Characterization of Colletotrichum spp. sensitivity to carbendazim for isolates causing strawberry anthracnose in China. Plant Disease, 105(1),87-95. https://doi.org/10.1094/PDIS-04-20-0875-RE

56. Zhou, Y., Gong, G., Cui, Y., Zhang, D., Chang, X., Hu, R., Liu, N., \& Sun, X. (2015). Identification of Botryosphaeriaceae species causing kiwifruit rot in Sichuan province, China. Plant Disease, 99(5), 699-708. https://doi.org/10.1094/PDIS-07-14-0727-RE

\section{Tables}

Table 1. Strain details of Colletotrichum species and outgroup used in the multi-gene phylogenetic analysis 


\begin{tabular}{|c|c|c|c|c|c|c|c|c|}
\hline \multirow[t]{2}{*}{ Species } & \multirow[t]{2}{*}{ Strain no. } & \multirow[t]{2}{*}{ Host } & \multirow[t]{2}{*}{ Location } & \multicolumn{4}{|c|}{ GenBank accession number } & \multirow[t]{2}{*}{ Reference } \\
\hline & & & & ITS $^{a}$ & GAPDH $^{b}$ & $\mathrm{ACT}^{\mathrm{c}}$ & $\mathrm{TUB2}^{\mathrm{d}}$ & \\
\hline $\begin{array}{l}\text { Colletotrichum } \\
\text { acutatum }\end{array}$ & $\begin{array}{l}\text { CBS } \\
112996\end{array}$ & Carica papaya & Australia & JQ005776 & JQ948677 & JQ005839 & JQ005860 & $\begin{array}{l}\text { O'Connell } \\
\text { et al., } 2012\end{array}$ \\
\hline $\begin{array}{l}\text { C. americae- } \\
\text { borealis }\end{array}$ & $\begin{array}{l}\text { CBS } \\
136232\end{array}$ & $\begin{array}{l}\text { Medicago } \\
\text { sativa }\end{array}$ & America & KM105224 & KM105579 & KM105434 & KM105504 & $\begin{array}{l}\text { Damm et } \\
\text { al., } 2014\end{array}$ \\
\hline C. anthrisci & $\begin{array}{l}\text { CBS } \\
125334\end{array}$ & $\begin{array}{l}\text { Anthriscus } \\
\text { sylvestris }\end{array}$ & Netherlands & GU227845 & GU228237 & GU227943 & GU228139 & $\begin{array}{l}\text { Damm et } \\
\text { al., } 2009\end{array}$ \\
\hline C. boninense & $\begin{array}{l}\text { CBS } \\
123755\end{array}$ & $\begin{array}{l}\text { Crinum } \\
\text { asiaticum }\end{array}$ & Japan & JQ005153 & JQ005240 & JQ005501 & JQ005588 & $\begin{array}{l}\text { Guarnaccia } \\
\text { et al., } 2019\end{array}$ \\
\hline C. brassicicola & CD015 & $\begin{array}{l}\text { Andean } \\
\text { blackberry }\end{array}$ & Colombia & JN715844 & KC860010 & KC859967 & KC860036 & $\begin{array}{l}\text { Afanador- } \\
\text { Kafuri et } \\
\text { al., } 2014\end{array}$ \\
\hline C. cliviae & CSSK4 & Clivia miniata & China & GQ485607 & GQ856756 & GQ856777 & GQ849440 & $\begin{array}{l}\text { Liu et al., } \\
2016\end{array}$ \\
\hline C. godetiae & AN014 & $\begin{array}{l}\text { Andean } \\
\text { blackberry }\end{array}$ & Colombia & JN715834 & KC860004 & KC859961 & KC860030 & $\begin{array}{l}\text { Afanador- } \\
\text { Kafuri et } \\
\text { al., } 2014\end{array}$ \\
\hline C. karstii & $\begin{array}{l}\text { CBS } \\
106.91\end{array}$ & Bambusoideae & China & JQ005220 & JQ005307 & JQ005568 & JQ005654 & $\begin{array}{l}\text { Wang et } \\
\text { al., } 2021\end{array}$ \\
\hline C. lilii & $\begin{array}{l}\text { CBS } \\
109214\end{array}$ & Lilium sp. & Japan & GU227810 & GU228202 & GU227908 & GU228104 & $\begin{array}{l}\text { Damm et } \\
\text { al., } 2009\end{array}$ \\
\hline C. liriopes & $\begin{array}{l}\text { CBS } \\
119444\end{array}$ & $\begin{array}{l}\text { Lirope } \\
\text { muscari }\end{array}$ & Mexico & GU227804 & GU228196 & GU227902 & GU228098 & $\begin{array}{l}\text { Damm et } \\
\text { al., } 2009\end{array}$ \\
\hline C. nigrum & CVG173 & Salvia greggii & Italy & MN516537 & MN535101 & MN535139 & MN535120 & $\begin{array}{l}\text { Guarnaccia } \\
\text { et al., } 2019\end{array}$ \\
\hline C. plurivorum & CPC28638 & $\begin{array}{l}\text { Capsicum } \\
\text { annuum }\end{array}$ & Thailand & MH805810 & MH805816 & MH805828 & MH805824 & $\begin{array}{l}\text { Silva et al., } \\
2019\end{array}$ \\
\hline C. scovillei & $\begin{array}{l}\text { CBS } \\
120708\end{array}$ & $\begin{array}{l}\text { Capsicum } \\
\text { annuum }\end{array}$ & Thailand & JQ948269 & JQ948599 & JQ949590 & JQ949920 & $\begin{array}{l}\text { Damm et } \\
\text { al., } 2012\end{array}$ \\
\hline C. siamense & CSST1 & $\begin{array}{l}\text { Hymenocallis } \\
\text { sp. }\end{array}$ & Thailand & GQ485602 & GQ849441 & GQ856758 & GQ856778 & $\begin{array}{l}\text { Yang et al., } \\
2009\end{array}$ \\
\hline C. sloanei & $\begin{array}{l}\text { IMI } \\
364297\end{array}$ & $\begin{array}{l}\text { Theobroma } \\
\text { cacao }\end{array}$ & Malaysia & JQ948287 & JQ948617 & JQ949608 & JQ949938 & $\begin{array}{l}\text { Silva et al., } \\
2019\end{array}$ \\
\hline C. sojae & $\begin{array}{l}\text { CBS } \\
128510\end{array}$ & Clivia miniata & China & MG600751 & MG600812 & MG600956 & MG601018 & $\begin{array}{l}\text { Damm et } \\
\text { al., } 2009\end{array}$ \\
\hline $\begin{array}{l}\text { C. } \\
\text { spaethianum* }\end{array}$ & HFCS1 & $\begin{array}{l}\text { Hemerocallis } \\
\text { flava }\end{array}$ & China & MW924459 & MW924461 & MW924463 & MW924465 & this study \\
\hline $\begin{array}{l}\text { C. } \\
\text { spaethianum* }\end{array}$ & HFCS2 & $\begin{array}{l}\text { Hemerocallis } \\
\text { flava }\end{array}$ & China & MW924460 & MW924462 & MW924464 & MW924466 & this study \\
\hline $\begin{array}{l}\text { C. } \\
\text { spaethianum }\end{array}$ & CSSX3 & $\begin{array}{l}\text { Hymenocallis } \\
\text { americana }\end{array}$ & China & GQ485584 & GQ856745 & GQ856767 & GQ849432 & $\begin{array}{l}\text { Yang et al., } \\
2009\end{array}$ \\
\hline $\begin{array}{l}\text { C. } \\
\text { spaethianum }\end{array}$ & - & $\begin{array}{l}\text { Hemerocallis } \\
\text { flava }\end{array}$ & Brazil & KC598120 & KC598118 & KC598114 & - & $\begin{array}{l}\text { Vieira et al., } \\
2014\end{array}$ \\
\hline C. tanaceti & UM01 & $\begin{array}{l}\text { Tanacetum } \\
\text { cinerariifolium }\end{array}$ & Australia & JX218228 & JX218243 & JX218238 & JX218233 & $\begin{array}{l}\text { Barimani et } \\
\text { al., } 2013\end{array}$ \\
\hline C. truncata & cSSX4 & $\begin{array}{l}\text { Hymenocallis } \\
\text { americana }\end{array}$ & China & GQ485590 & GQ856755 & GQ856768 & GQ849425 & $\begin{array}{l}\text { Yang et al., } \\
2009\end{array}$ \\
\hline $\begin{array}{l}\text { Alternaria } \\
\text { alternata }\end{array}$ & AA2-8 & Sonchus asper & China & MH886523 & MN655782 & MH892480 & - & $\begin{array}{l}\text { Zhang et } \\
\text { al., 2020a }\end{array}$ \\
\hline
\end{tabular}

a, internal transcribed spacers 1 and 2 together with $5.8 \mathrm{~S}$ nrDNA; b, partial glyceraldehyde-3-phosphate dehydrogenase gene; $c$, partial actin gene; d, partial beta-tubulin gene. \#, outgroups used to construct multigene phylogenetic tree. *, Sequences generated in this study are 
indicated in bolds.

Table 2. Detected fungicides used in this study

\begin{tabular}{|c|c|c|c|c|}
\hline $\begin{array}{l}\text { Name of } \\
\text { fungicides }\end{array}$ & $\begin{array}{l}\text { Effective } \\
\text { concentrations }\end{array}$ & $\begin{array}{l}\text { Fungicide } \\
\text { types }\end{array}$ & Manufacture factories & $\begin{array}{l}\text { Experimental } \\
\text { concentrations } \mathrm{BD} / \mathrm{mL} \mathrm{V}\end{array}$ \\
\hline zineb & $70 \%$ & WPa & Jinan Ri You Agrochemical Co. Ltd, China & $0.5,1,5,20$ \\
\hline difenoconazole & $10 \%$ & $W G^{b}$ & $\begin{array}{l}\text { Syngenta Nantong Crop Protection Co. } \\
\text { Ltd, China }\end{array}$ & $0.5,1,5,20$ \\
\hline captan & $50 \%$ & WP & Adama Co. Ltd, China & $0.5,1,5,20$ \\
\hline carbendazim & $50 \%$ & WP & $\begin{array}{l}\text { Shanghai YUELIAN Chemical Co. Ltd, } \\
\text { China }\end{array}$ & $0.1,0.5,5,25$ \\
\hline
\end{tabular}

a, wettable powder; $b$, waterdispersible granules

Table 3. Toxic regression equation of four fungicides against the pathogenic fungi of daylily anthracnose

\begin{tabular}{|c|c|c|c|c|c|c|c|}
\hline \multicolumn{4}{|l|}{ HFCS1 } & \multicolumn{4}{|l|}{ HFCS2 } \\
\hline $\begin{array}{l}\text { Tested } \\
\text { fungicides }\end{array}$ & $\begin{array}{l}\text { Toxic } \\
\text { regression } \\
\text { equation }\end{array}$ & 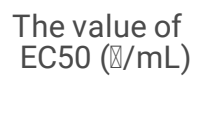 & $\begin{array}{l}\text { Correlation } \\
\text { index }\end{array}$ & $\begin{array}{l}\text { Tested } \\
\text { fungicides }\end{array}$ & $\begin{array}{l}\text { Toxic } \\
\text { regression } \\
\text { equation }\end{array}$ & $\begin{array}{l}\text { The value of } \\
\text { EC50 }(\varangle / \mathrm{mL})\end{array}$ & $\begin{array}{l}\text { Correlation } \\
\text { index }\end{array}$ \\
\hline 70\% Zineb WP & $\begin{array}{l}y=0.2918 x+ \\
0.4578\end{array}$ & 1.3950 & 0.9736 & 70\% Zineb WP & $\begin{array}{l}y=0.1812 x+ \\
0.433\end{array}$ & 2.3429 & 0.9886 \\
\hline $\begin{array}{l}10 \% \\
\text { Difenoconazole } \\
\text { WG }\end{array}$ & $\begin{array}{l}y=0.1999 x+ \\
0.5706\end{array}$ & 0.4434 & 0.9607 & $\begin{array}{l}10 \% \\
\text { Difenoconazole } \\
\text { WG }\end{array}$ & $\begin{array}{l}y=0.2217 x+ \\
0.7315\end{array}$ & 0.0903 & 0.9233 \\
\hline $\begin{array}{l}50 \% \text { Captan } \\
\text { WP }\end{array}$ & $\begin{array}{l}y=0.1922 x+ \\
0.3987\end{array}$ & 3.4020 & 0.9766 & $\begin{array}{l}50 \% \text { Captan } \\
\text { WP }\end{array}$ & $\begin{array}{l}y=0.198 x+ \\
0.4541\end{array}$ & 1.7054 & 0.9752 \\
\hline $\begin{array}{l}50 \% \\
\text { Carbendazim } \\
\text { WP }\end{array}$ & $\begin{array}{l}y=0.1695 x+ \\
0.5857\end{array}$ & 0.3120 & 0.954 & $\begin{array}{l}50 \% \\
\text { Carbendazim } \\
\text { WP }\end{array}$ & $\begin{array}{l}y=0.1032 x+ \\
0.5289\end{array}$ & 0.5248 & 0.9626 \\
\hline
\end{tabular}

\section{Figures}




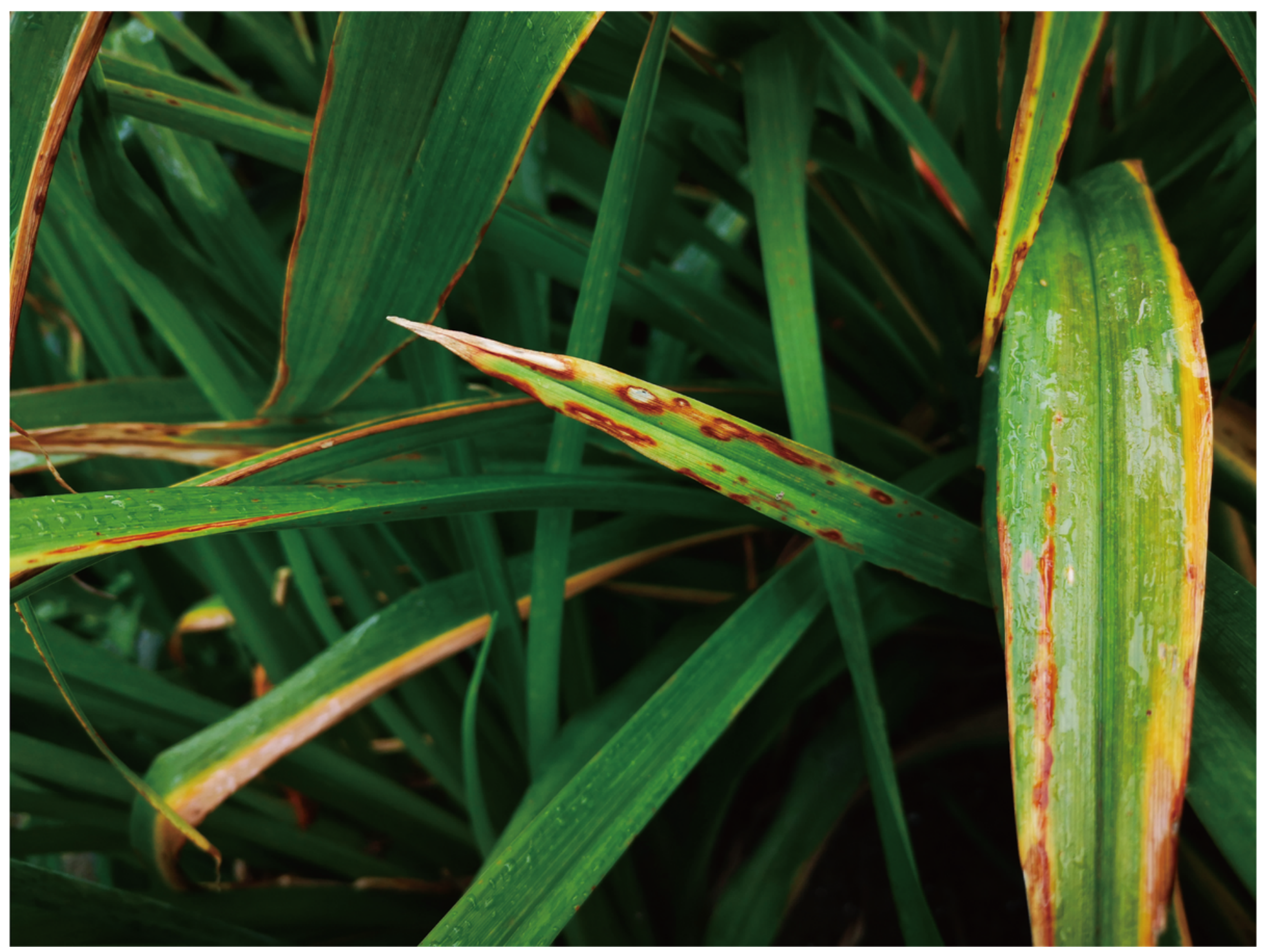

Figure 1

Symptoms of anthracnose on daylily in the field

The pictures were taken from the collection site of the experimental samples. 


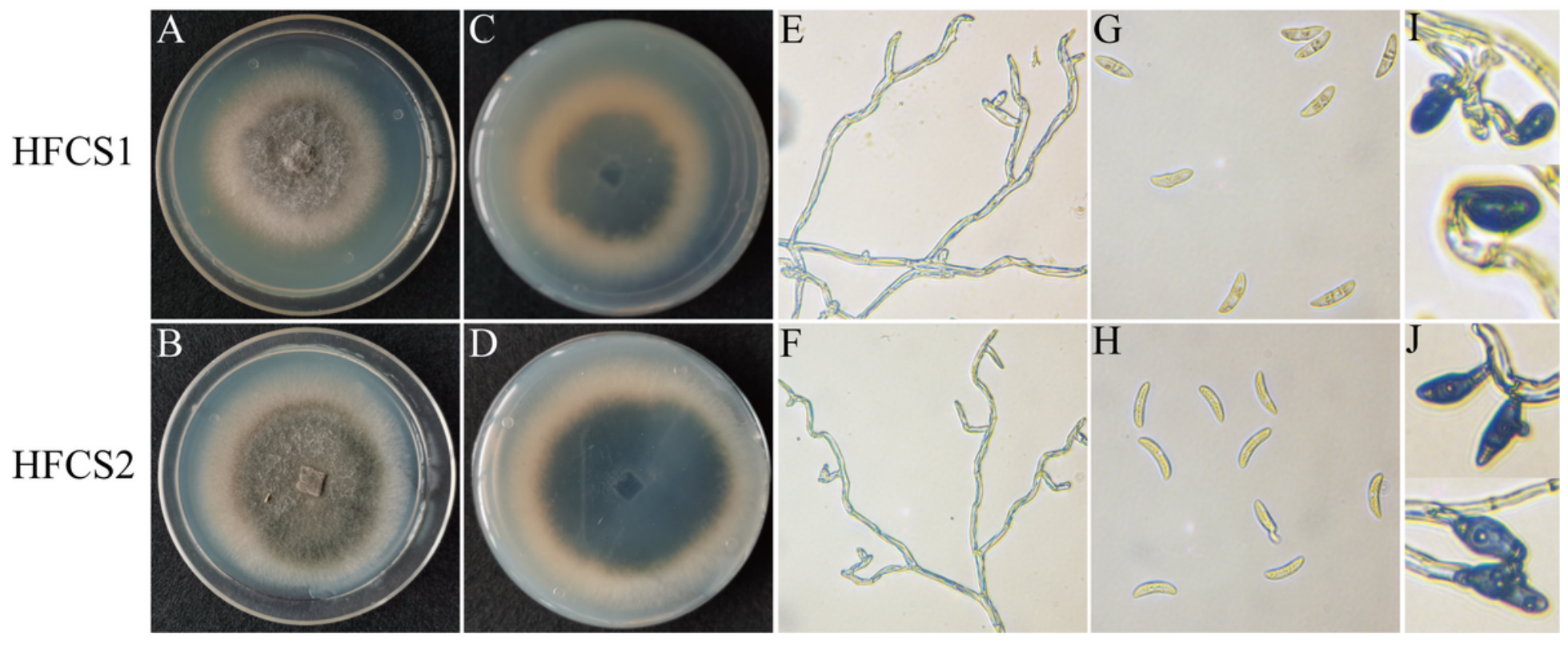

Figure 2

Morphological characteristics of HFCS1 and HFCS2

A-B, colony's upper surface. C-D, colony's lower surface. E-F, mycelia. G-H, conidia. I-J, appressoria. Scale bars: A-F $=20 \mu \mathrm{m}, \mathrm{G}-\mathrm{J}=10 \mu \mathrm{m}$. 


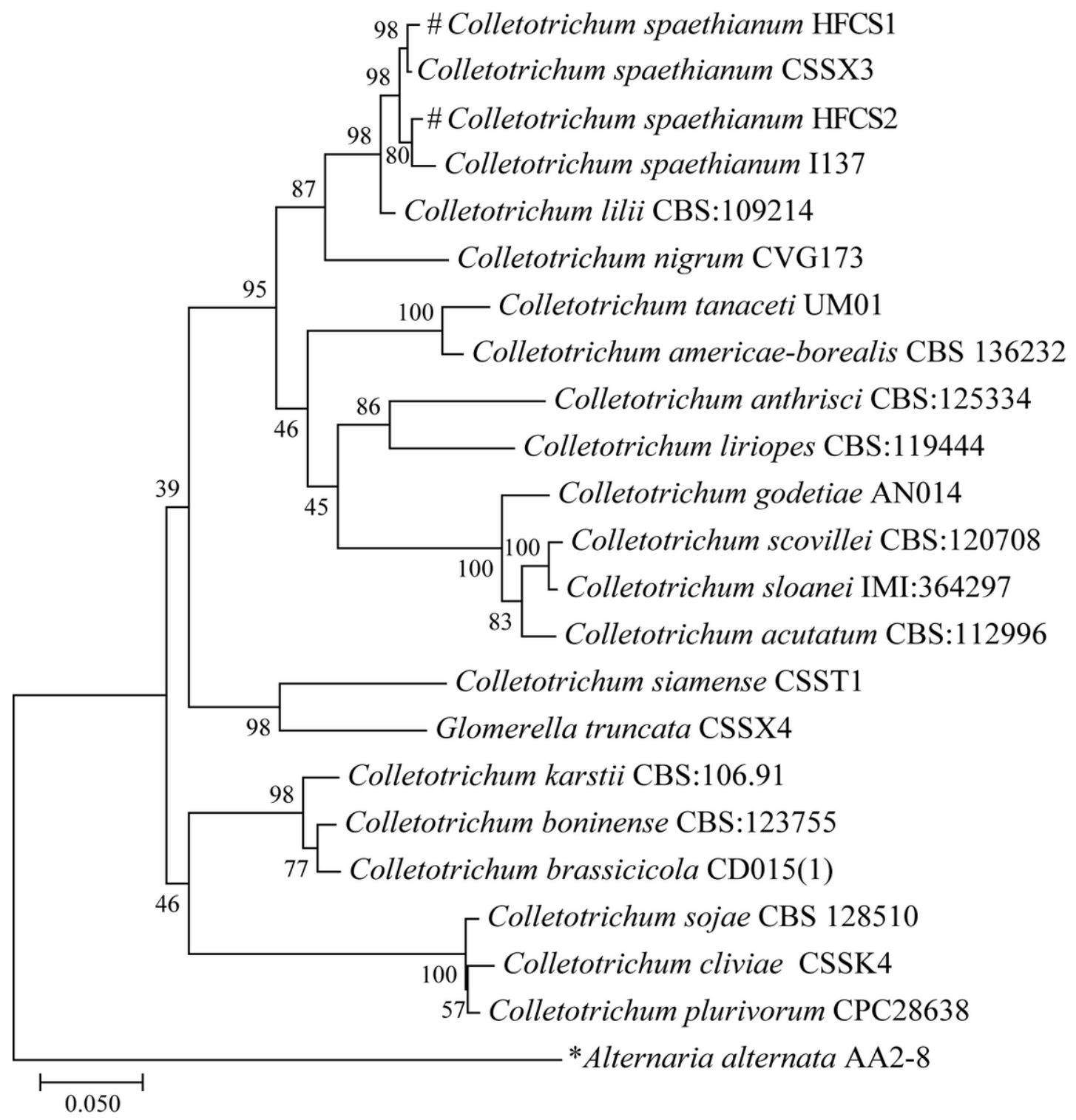

Figure 3

Multigene phylogenetic tree (ITS, GAPDH, ACT, and TUB2 genes) of two isolates from daylily and from other species with Alternaria alternata (strain: AA2-8) as the outgroup

The multigene phylogenetic tree was performed on the multilocus alignment (ITS, GAPDH, ACT, and TUB2 genes) and carried out using maximum likelihood by MEGA7.0 with 1000 bootstrap replicates. "*” means the outgroup, "\#” means the isolates from daylily in this study. 


\section{Leaves inoculated with the fungus}

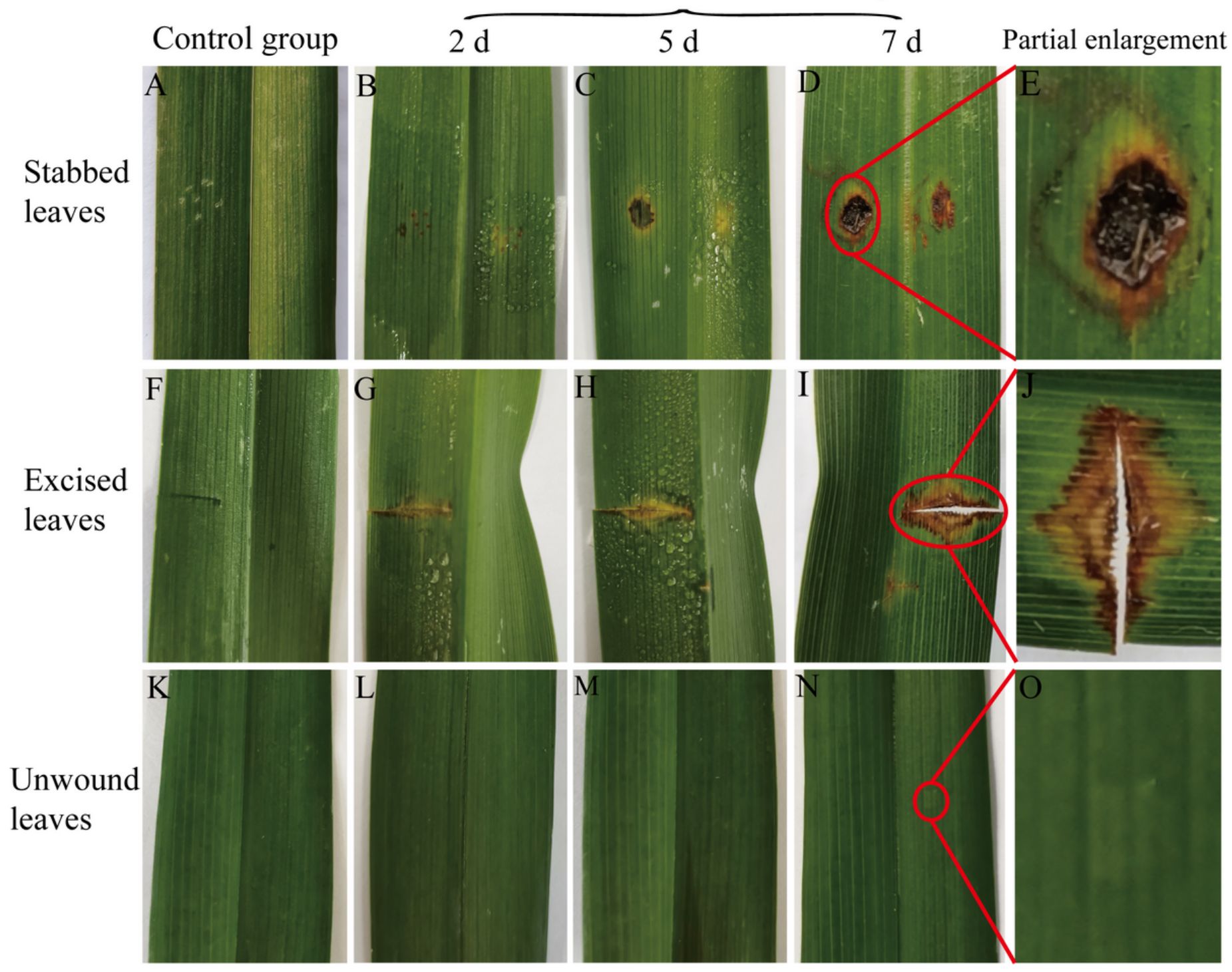

Figure 4

Symptoms of daylily leaves inoculated with HFCS1

$\mathrm{A}, \mathrm{F}$ and $\mathrm{K}$ showed the controls for stabbed leaves, excised leaves and non-wounded leaves, respectively. B, C and D showed stabbed leaves inoculated with the fungus for $2 \mathrm{~d}, 5 \mathrm{~d}$, and $7 \mathrm{~d}$, respectively. G, $\mathrm{H}$ and I showed excised leaves inoculated with the fungus for $2 \mathrm{~d}, 5 \mathrm{~d}$ and $7 \mathrm{~d}$, respectively. L, $\mathrm{M}$ and $\mathrm{N}$ showed non-wounded leaves inoculated with the fungus for $2 \mathrm{~d}, 5 \mathrm{~d}$ and $7 \mathrm{~d}$, respectively. $\mathrm{E}, \mathrm{J}$ and $\mathrm{O}$ showed partial enlargement for stabbed leaves, excised leaves and non-wounded leaves, respectively. 


\section{HFCS1}

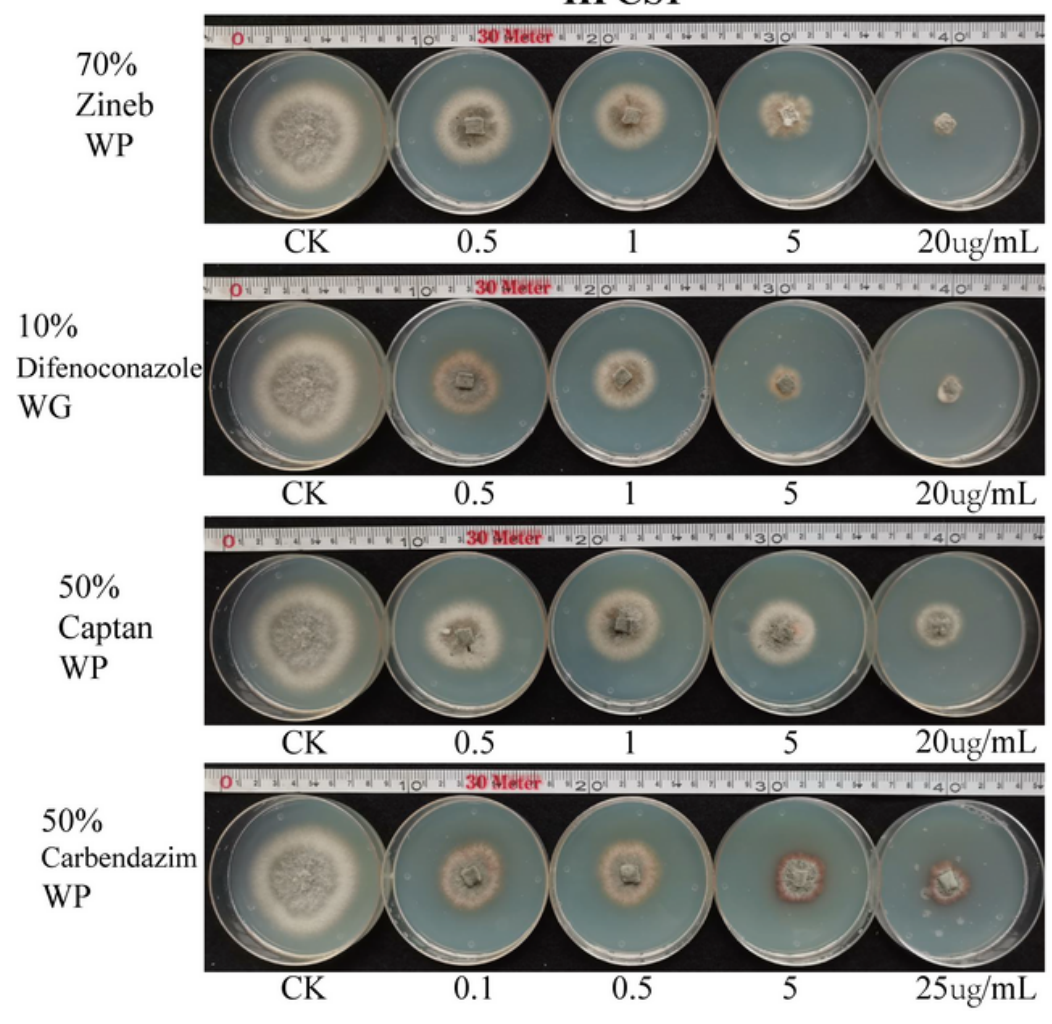

\section{HFCS2}
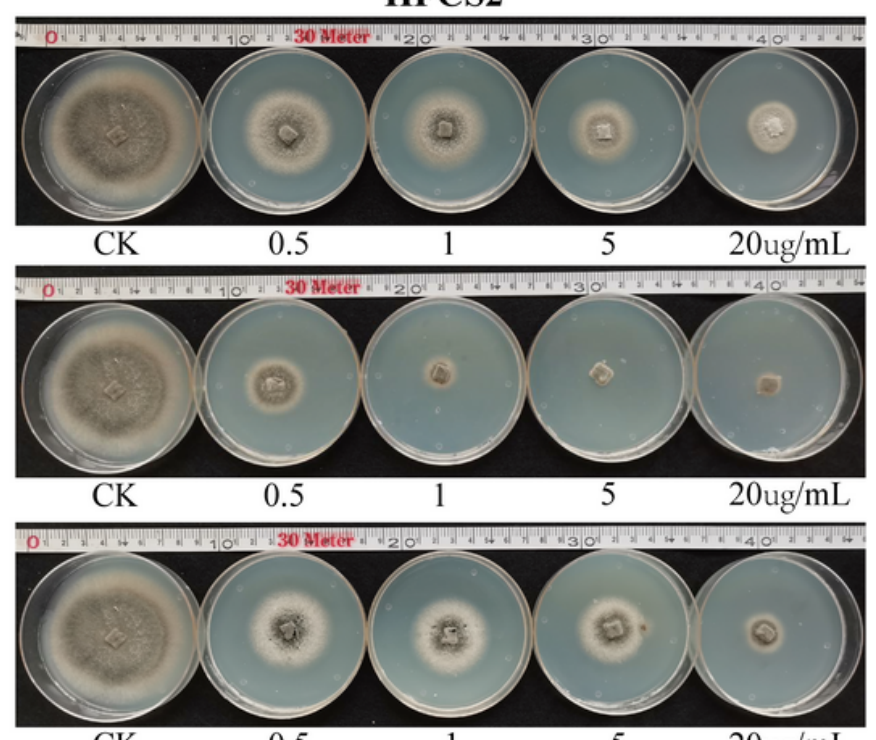

CK

0.5

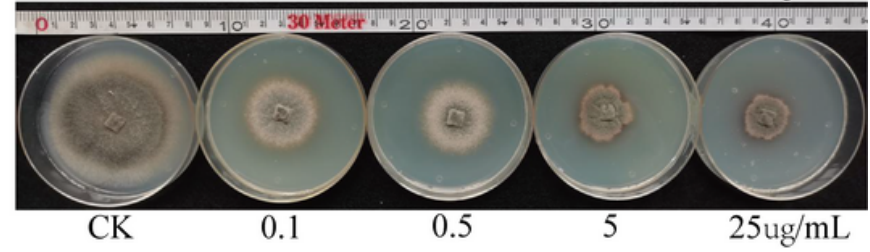

\section{Figure 5}

The pathogenic fungi of daylily anthracnose grew on PDA supplemented with fungicides

Mycelial plugs from two isolates of daylily anthracnose were cultured on PDA plates with different concentrations of four fungicides for seven days. CK denotes that mycelial plugs were cultured on PDA plates with the same amount of sterile water for seven days.

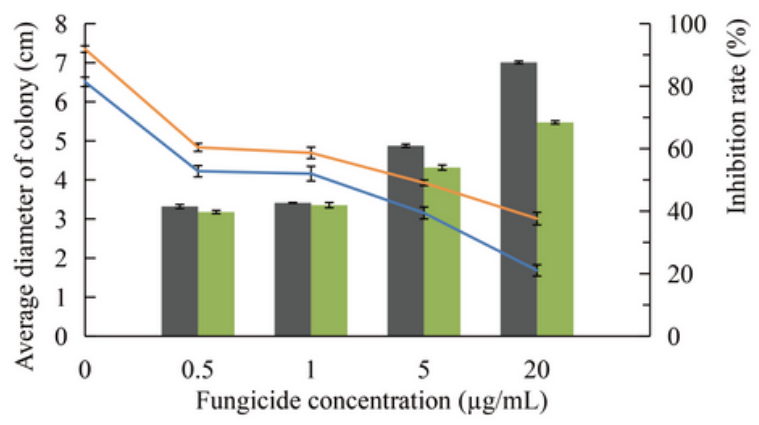

$\mathbf{7 0 \%}$ Zineb WP

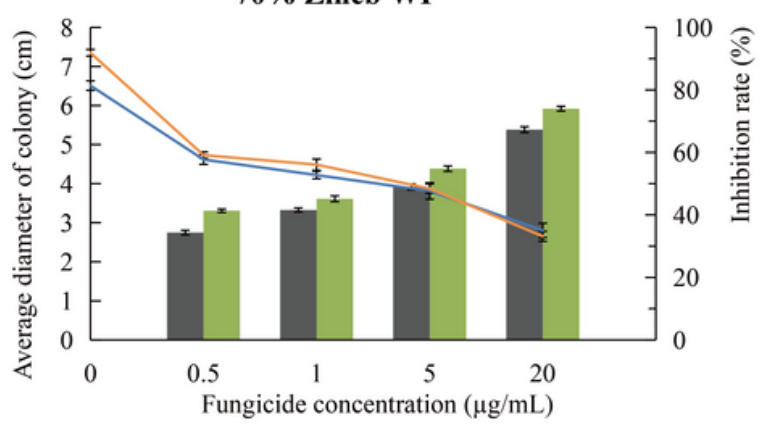

$\mathbf{5 0 \%}$ Captan WP

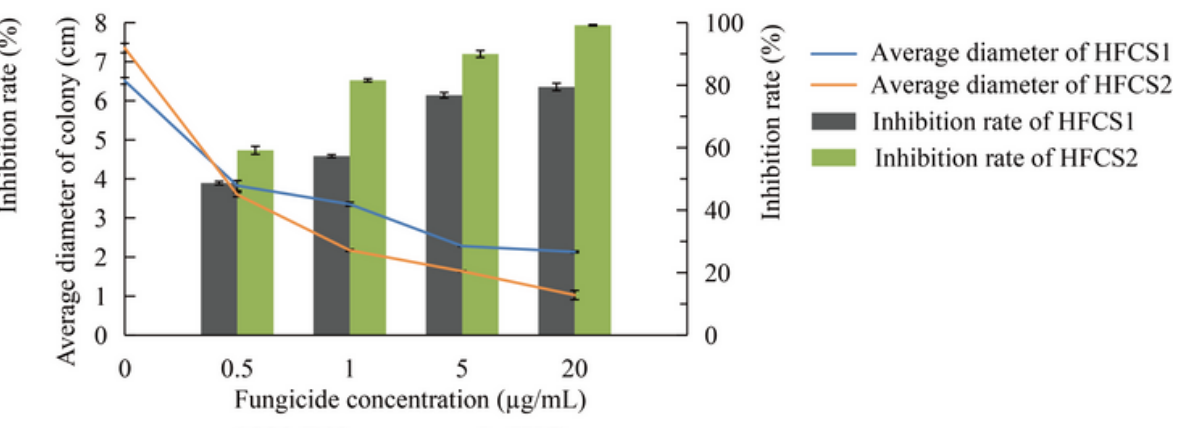

$10 \%$ Difenoconazole WG

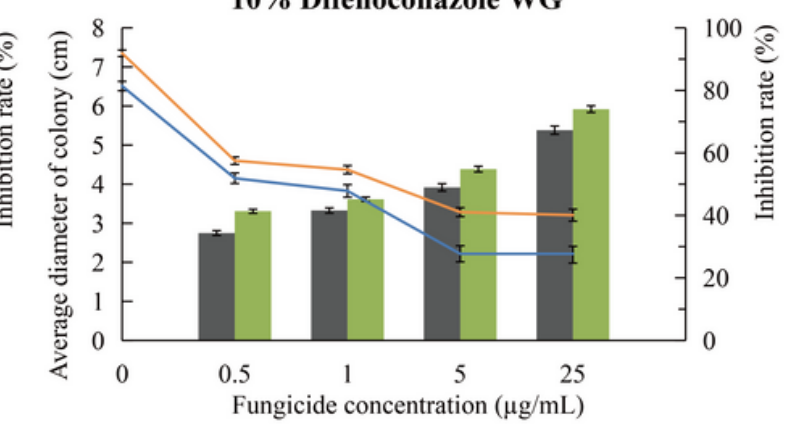

$\mathbf{5 0} \%$ Carbendazim WP

Figure 6 
Inhibition efficiency of four fungicides on the pathogenic fungi of daylily anthracnose

All the colony diameter were measured by using the cross measurement method after seven days of cultivation.

\section{Supplementary Files}

This is a list of supplementary files associated with this preprint. Click to download.

- Attachedfile.docx 